\title{
Analisis Produktivitas dan Faktor-Faktor yang Memengaruhi Efisiensi Asuransi Syariah di Indonesia: Suatu Kajian Empiris
}

\section{Productivity Analysis and Determinants of Islamic Insurance Efficiency in Indonesia: An Empirical Study}

\author{
Dede Iskandar ${ }^{1}$, Noer Azam Achsani ${ }^{2}$, Setiadi Djohar ${ }^{3}$ \\ ${ }^{1}$ Sekolah Bisnis Institut Pertanian Bogor, Jalan Raya Pajajaran, Bogor 16151, dd.iskandar@yahoo.com \\ ${ }^{2}$ Sekolah Bisnis Institut Pertanian Bogor, Jalan Raya Pajajaran, Bogor 16151, achsani@yahoo.com \\ ${ }^{3}$ Sekolah Bisnis Institut Pertanian Bogor, Jalan Raya Pajajaran, Bogor 16151, sdjohar@gmail.com
}

\begin{abstract}
Market share on Islamic Insurance is still very small compared to conventional insurance. Islamic insurance companies must be able to compete with conventional insurance in order to increase their market share. Efficiency and Productivity are factors that must be improved so that Islamic insurance can compete with conventional insurance. This study aims to analyze the level of efficiency and productivity of Islamic insurance during the 2016-2018 period. The study was conducted on 48 Islamic insurance companies consisting of 26 Islamic life insurance companies and 22 Islamic general insurance companies. Efficiency analysis use the Data Envelopment Analysis (DEA) approach and productivity analysis use the Malmquist Productivity Index (MPI). The novelty of this study, among others, involves Islamic general insurance in the productivity analysis which has not been studied so far. The results of the analysis shows that the majority of Islamic life insurance and Islamic general insurance are inefficient during the 2016-2018 period. The size of the company which represents the total assets is the factor that have a positive and significant effect on the efficiency value. The results of the productivity analysis shows that the productivity level of both sharia life insurance and general sharia insurance during the 2016-2018 period is influenced by technological change factors.
\end{abstract}

Keywords: Data Envelopment Analysis (DEA), efficiency, Islamic insurance, Malmquist Productvity Index (MPI), productivity

\begin{abstract}
Abstrak. Pangsa pasar industri asuransi syariah masih sangat kecil dibandingkan dengan asuransi konvensional. Perusahaan asuransi syariah harus dapat bersaing dengan asuransi konvensional untuk meningkatkan pangsa pasarnya. Efisiensi dan produktivitas merupakan faktor-faktor yang harus ditingkatkan sehingga asuransi syariah dapat bersaing dengan asuransi konvensional. Penelitian ini bertujuan untuk menganalisis tingkat efisiensi dan produktivitas asuransi syariah selama periode 20162018. Penelitian dilakukan terhadap 48 perusahaan asuransi syariah yang terdiri dari 26 perusahaan asuransi jiwa syariah dan 22 perusahaan asuransi umum syariah. Analisis efisiensi menggunakan pendekatan Data Envelopment Analysis (DEA) dan analisis produktivitas menggunakan Malmquist Productivity Index (MPI). Kebaruan dari penelitian ini diantaranya melibatkan asuransi umum syariah dalam analisis produktivitas yang selama ini belum diteliti. Hasil dari analisis menunjukkan bahwa mayoritas asuransi jiwa syariah dan asuransi umum syariah tidak efisien selama periode 2016-2018. Ukuran (size) perusahaan yang mewakili jumlah aset merupakan faktor yang berpengaruh positif dan signifikan pada nilai efisiensi. Hasil dari analisis produktivitas menunjukkan bahwa tingkat produktivitas asuransi jiwa syariah maupun asuransi umum syariah selama periode 2016-2018 dipengaruhi oleh faktor perubahan teknologi.
\end{abstract}

Kata kunci: Asuransi Syariah, Data Envelopment Analysis (DEA), efisiensi, Malmquist Productvity Index (MPI), produktivitas

\section{PENDAHULUAN}

Industri asuransi syariah di Indonesia mengalami perkembangan setiap tahunnya. Hal ini terlihat dari jumlah perusahaan asuransi syariah di Indonesia yang terus bertambah sejak tahun 1994 yaitu saat pertama kali asuransi syariah beroperasi di Indonesia. Berdasarkan data OJK tercatat per 31 Desember 2018, jumlah perusahaan asuransi dan perusahaan reasuransi dengan prinsip syariah sebanyak 62 perusahaan yang terdiri dari 12 perusahaan asuransi syariah (murni syariah), 1 perusahaan reasuransi 
syariah (murni syariah), 47 perusahaan asuransi yang memiliki unit syariah, dan 2 perusahaan reasuransi yang memiliki unit syariah. Asuransi syariah menurut Fatwa Dewan Syariah Nasional No. 21/DSN-MUI/X/2001 tentang Pedoman Umum Asuransi Syariah didefiniskan sebagai usaha saling melindungi dan tolong menolong di antara sejumlah orang/pihak melalui investasi dalam bentuk aset dan atau dana tabarru' yang memberikan pola pengembalian untuk menghadapi risiko tertentu melalui akad (perikatan) yang sesuai dengan syariah.

Perbedaan utama asuransi syariah dengan asuransi konvensional menurut Maksum (2011) yaitu pada tujuan dan landasan operasional. Asuransi syariah bertujuan untuk saling tolong menolong (ta' awuni), sedangkan asuransi konvensional tujuannya adalah penggantian (tabaduli). Berdasarkan aspek operasionalnya, asuransi konvensional berlandaskan pada peraturan perundangan sedangkan asuransi syariah dalam aspek operasionalnya berlandaskan pada peraturan perundangan dan ketentuan syariah.

Industri asuransi syariah meskipun mengalami pertumbuhan setiap tahunnya namun jika dibandingkan dengan asuransi konvensional, pangsa pasar asuransi syariah masih sangat kecil. Pangsa pasar asuransi syariah terhadap industri asuransi di Indonesia baik dari sisi kontribusi maupun aset masih di kisaran 5\% pada tahun 2017 dan 2018 (Tabel 1).

Tabel 1 Pangsa pasar asuransi syariah tahun 2017-2018

\begin{tabular}{|c|c|c|c|c|c|}
\hline \multirow{2}{*}{ No. } & \multirow{2}{*}{ Keterangan } & \multicolumn{2}{|c|}{ Kontribusi Bruto* } & \multicolumn{2}{|c|}{ Aset* } \\
\hline & & 2017 & 2018 & 2017 & 2018 \\
\hline \multirow[t]{3}{*}{ I. } & Seluruh Asuransi Jiwa & 194.42 & 196.92 & 546.53 & 555.38 \\
\hline & Asuransi Jiwa Syariah & 11.09 & 12.66 & 33.19 & 34.28 \\
\hline & Persentase Asuransi Jiwa Syariah & 5.70 & 6.43 & 6.07 & 6.17 \\
\hline \multirow[t]{3}{*}{ II. } & $\begin{array}{l}\text { Seluruh Asuransi Umum dan } \\
\text { Reasuransi }\end{array}$ & 70.42 & 77.46 & 154.46 & 173.36 \\
\hline & $\begin{array}{l}\text { Asuransi Umum dan Reasuransi } \\
\text { Syariah }\end{array}$ & 2.65 & 2.75 & 7.34 & 7.32 \\
\hline & $\begin{array}{l}\text { Persentase Asuransi Umum dan } \\
\text { Reasuransi Syariah }\end{array}$ & 3.76 & $\mathbf{3 . 5 5}$ & 4.75 & 4.22 \\
\hline \multirow[t]{3}{*}{ III. } & $\begin{array}{l}\text { Seluruh Asuransi (Life and Non } \\
\text { Life) }\end{array}$ & 264.83 & 274.38 & 700.98 & 728.74 \\
\hline & $\begin{array}{l}\text { Seluruh Asuransi Syariah (Life and } \\
\text { Non Life Sharia) }\end{array}$ & 13.74 & 15.41 & 40.53 & 41.60 \\
\hline & $\begin{array}{l}\text { Persentase Seluruh Asuransi } \\
\text { Syariah (Life and Non Life Sharia) }\end{array}$ & 5.19 & 5.62 & 5.78 & 5.71 \\
\hline
\end{tabular}

Potensi untuk mengembangkan asuransi syariah di Indonesia masih sangat besar mengingat Indonesia merupakan negara dengan mayoritas penduduknya beragama Islam. Selain itu, kesadaran umat Muslim Indonesia untuk menggunakan produk-produk yang berlabel halal terus meningkat. Pandemi Covid-19 (Corona Virus Disease 2019) yang saat ini melanda dunia (termasuk Indonesia) membuat orang semakin peduli untuk memiliki perlindungan terhadap risiko jiwa dan kesehatan sehingga akan meningkatkan kepedulian masyarakat untuk memiliki asuransi jiwa dan kesehatan. Hal ini tentunya menjadi peluang bagi industri asuransi syariah untuk meningkatkan pangsa pasarnya di Indonesia. Menurut Majid et al. (2017) perusahaan asuransi harus meningkatkan efisiensi serta produktivitasnya untuk menghadapi tantangan persaingan.

Efisiensi merupakan salah satu parameter yang mencerminkan performa perusahaan (Antonio et al., 2013). Menurut Khan \& Noreen (2014), efisiensi sangat penting bagi perusahaan asuransi syariah untuk bersaing dengan asuransi konvensional. Peningkatan efisiensi dapat membuat perusahaan asuransi syariah lebih kompetitif (Lee et al., 2018). Selain itu, untuk meningkatkan pangsa pasar 
perusahaan asuransi syariah juga harus meningkatkan produktivitasnya. Oleh karena itu, penelitian tentang efisiensi dan produktivitas asuransi syariah penting untuk dilakukan. Penelitian ini bertujuan untuk mengukur dan melakukan analisis tingkat efisiensi dan produktivitas industri asuransi syariah di Indonesia.

Saat ini, penelitian-penelitian yang telah dilakukan terkait pengukuran efisiensi dan produktivitas asuransi syariah di Indonesia masih sangat sedikit, diantaranya Benarda et al. (2016), Sabiti et al. (2017) dan Sunarsih \& Fitriyani (2018). Umumnya penelitian tentang tingkat produktivitas juga meneliti tentang tingkat efisiensi karena dalam mengukur tingkat produktivitas menggunakan perubahan nilai efisiensi, seperti Barros et al. (2005), Cummins \& Xie (2013), Chakraborty et al. (2013), Yaisawarng et al. (2014) serta Bienera et al. (2015). Penelitian tentang tingkat produktivitas asuransi syariah di Indonesia baru dilakukan terhadap perusahaan asuransi jiwa syariah (Suryoaji \& Cahyono, 2019), namun belum melibatkan perusahaan asuransi umum syariah sehingga penelitian ini dimaksudkan untuk memenuhi ketiadaan tersebut.

Penelitian ini memiliki dua tujuan utama. Tujuan pertama untuk menghitung tingkat efisiensi serta menganalisis faktor-faktor yang memengaruhi tingkat efisiensi industri asuransi syariah di Indonesia. Kedua, menganalisis tingkat produktivitas industri asuransi syariah di Indonesia untuk mengetahui tren produktivitas industri asuransi syariah di Indonesia selama periode 2016-2017. Kebaruan dari penelitian ini selain menganalisis tingkat produktivitas asuransi umum syariah yang saat ini belum dilakukan, di antaranya yaitu penggunaan jumlah sampel yang lebih banyak sehingga dapat lebih mencerminkan kondisi industri asuransi syariah serta penggunaan variabel yang berbeda dan periode data yang lebih mutakhir. Hasil penelitian ini juga dapat dijadikan pertimbangan terkait ketentuan dalam Undang-Undang No. 40 tahun 2014 tentang Perasuransian Pasal 87 yang menyatakan bahwa paling lambat tahun 2024 setiap unit syariah dari perusahaan asuransi maupun perusahaan reasuransi wajib untuk melakukan pemisahan (spin off).

\section{TINJAUAN PUSTAKA}

\section{Konsep Efisiensi}

Efisiensi merupakan kemampuan menjalankan tugas dengan baik dan tepat yaitu dengan mengoptimalkan penggunaan waktu, tenaga serta biaya. Konsep efisiensi menurut Ascarya \& Yumanita (2006) bermula dari teori produsen dan teori konsumen. Teori produsen menjelaskan bahwa produsen memiliki kecenderungan untuk memaksimalkan keuntungan dan meminimalkan biaya. Sedangkan teori konsumen menyatakan bahwa konsumen memiliki kecenderungan untuk memaksimalkan tingkat utilitas atau tingkat kepuasannya.

Rusydiana et al. (2019) menjelaskan bahwa efisiensi dalam sudut pandang perusahaan dibedakan menjadi tiga jenis efisiensi, yaitu: efisiensi teknis, efisiensi alokatif dan efisiensi ekonomi. Efisiensi teknis mencerminkan kemampuan perusahaan untuk menghasilkan output yang optimal dengan penggunaan level input tertentu. Sedangkan efisiensi alokatif merupakan kemampuan perusahaan dalam mengoptimalkan penggunaan input dengan struktur harga dan teknologinya. Adapun efisiensi ekonomi merupakan kombinasi antara efisiensi teknikal dan alokatif. Suatu perusahaan dapat dikatakan efisien secara ekonomi tingkat produksinya apabila perusahaan tersebut menggunakan biaya per unit output yang paling minimal.

Pengukuran efisiensi perusahaan asuransi pada penelitian-penelitian awal menggunakan perhitungan parsial seperti analisis rasio. Perhitungan efisiensi secara parsial menurut Berger dan Humphrey (1992) dalam Hartono et al. (2008) akan memberikan hasil perhitungan yang kurang tepat. Penelitianpenelitian pada beberapa tahun terakhir tentang pengukuran efisiensi lembaga keuangan (termasuk asuransi) mayoritas merupakan perhitungan frontier efficiency atau $x$-efficiency dan tidak lagi menggunakan perhitungan parsial. Efisiensi frontier dari suatu lembaga keuangan diukur berdasarkan beberapa faktor input atau output yang memengaruhi efisiensi suatu lembaga keuangan. 
Ascarya \& Yumanita (2006) menyatakan bahwa frontier efficiency cukup superior bagi sebagian besar standar rasio keuangan dari laporan keuangan, seperti return on asset atau cost/revenue ratio yang umumnya digunakan oleh regulator, manajer lembaga keuangan atau konsultan industri dalam mengevaluasi kinerja keuangan. Frontier efficiency superior karena ukuran dari frontier efficiency menggunakan teknik pemrograman atau statistik yang menghilangkan pengaruh dari perbedaan di dalam harga input dan faktor pasar eksogen lainnya yang memengaruhi kinerja standar (rasio) dalam rangka untuk mendapatkan estimasi yang terbaik berdasarkan kinerja dari para manajer.

Pengukuran efisiensi dengan menggunakan pendekatan frontier ini pertama kali diprakarsai oleh Farrel (1957), bekerja sama dengan Debreu dan Koopmans. Sejak saat itu penelitian tentang efisiensi suatu perusahaan semakin berkembang. Penelitian pengukuran efisiensi pada awalnya banyak dilakukan untuk mengukur efisiensi lembaga perbankan. Namun beberapa tahun terakhir penelitian efisiensi semakin luas dan berkembang pada pengukuran efisiensi jenis lembaga/perusahaan yang lain, di antaranya seperti asuransi, rumah sakit, lembaga pendidikan, lembaga zakat, dan koperasi.

Pengukuran efisiensi frontier dapat menggunakan dua pendekatan yaitu pendekatan parametrik dan nonparametrik. Menurut Ascarya \& Yumanita (2008), pendekatan parametrik melakukan pengukuran dengan menggunakan ekonometrik yang stokastik dan berusaha untuk menghilangkan gangguan dari pengaruh ketidakefisienan. Terdapat tiga pendekatan parametrik, yaitu Stochastic Frontier Approach (SFA), Thick Frontier Approach (TFA) dan Distribution-free Approach (DFA). Sedangkan pendekatan nonparametrik dengan program linear dan tidak menggunakan pendekatan stokastik serta cenderung mengombinasikan gangguan dan ketidakefisienan. Pendekatan nonparametrik yaitu Data Envelopment Analysis (DEA) dan Free Disposable Hull (FDH).

Hadad et al. (2003) menyatakan bahwa baik menggunakan pendekatan parametrik maupun nonparametrik akan memperoleh hasil perhitungan yang hampir sama. Metode Data Envelopment Analysis (DEA) menurut Hadad et al. (2003) mempunyai beberapa keuntungan dibandingkan pendekatan parametrik. Dalam mengukur efisiensi, DEA mengidentifikasi unit yang digunakan sebagai referensi yang dapat membantu untuk mencari penyebab serta jalan keluar dari ketidakefisienan dan merupakan keuntungan utama dalam aplikasi manajerial. Selain itu, DEA tidak memerlukan spesifikasi yang lengkap dari bentuk fungsi yang menunjukkan hubungan produksi dan distribusi dari observasi.

Pengukuran efisiensi dengan metode DEA dapat dilakukan dengan pengukuran berorientasi input atau pengukuran berorientasi output. Pengukuran berorientasi input merupakan pendekatan yang berupaya untuk meminimalkan penggunaan input untuk menghasilkan jumlah output yang sama, sedangkan pengukuran berorientasi output yaitu berupaya untuk memaksimalkan output tanpa melakukan penambahan input atau dengan memanfaatkan input-input yang ada. Pendekatan berorientasi input digunakan pada saat kondisi pasar sudah jenuh sehingga perusahaan sulit untuk meningkatkan outputnya, sedangkan pendekatan berorientasi output digunakan pada saat kondisi pasar masih bagus.

\section{Konsep Produktivitas}

Produktivitas merupakan salah satu ukuran yang dapat digunakan untuk menilai kinerja perusahaan. Menurut Sulaeman (2014), produktivitas merupakan perbandingan antara jumlah output yang dihasilkan dengan jumlah sumber daya yang digunakan. Produktivitas seringkali dijadikan indikator keberhasilan perusahaan dalam menjalankan bisnisnya sehingga pengukuran produktivitas menjadi sangat penting bagi suatu perusahaan.

Produktivitas dapat diukur secara parsial yaitu perbandingan output terhadap suatu input, seperti produktivitas per tenaga kerja atau produktivitas per kapital. Pengukuran produktivitas secara parsial dapat melihat pengaruh suatu input terhadap output yang dihasilkan. Namun, menurut Coelli et al. (2005) pengukuran secara parsial sangat terbatas penggunaannya dan berpotensi salah dalam menggambarkan kinerja perusahaan. Total Factor Productivity (TFP) mengukur produktivitas perusahaan yang dalam proses produksinya dipengaruhi oleh banyak input dan banyak output, 
sehingga pengukuran ini lebih sesuai digunakan untuk pengukuran dan perbandingan kinerja baik antarperusahaan maupun kinerja satu perusahaan yang sama untuk beberapa periode waktu berbeda.

Pengukuran produktivitas dengan TFP menggunakan angka indeks yang dapat mengukur perubahan harga dan kuantitas sepanjang waktu (Rusydiana, 2018). Ilustrasi TFP index adalah sebagai berikut : Apabila output yang dihasilkan perusahaan sama untuk periode $t$ dan $t+1$ namun dengan penggunaan input diperiode $\mathrm{t}+1$ sebesar $80 \%$ dari input di periode $\mathrm{t}$, maka TFP index sebesar $1 / 0.8=1.25$. Ilustrasi lain, jika perusahaan menggunakan input yang sama pada periode $t$ dan $t+1$ namun terjadi peningkatan output di periode $\mathrm{t}+1$ sebesar $25 \%$, maka TFP index sebesar $1.25 \%$.

Beberapa metode yang dapat digunakan untuk mengukur produktivitas di antaranya: Fisher Index, Tornqvist Index, dan Malmquist Index. Malmquist Index menurut Suzuki \& Sastrosuwito (2011) memiliki tiga keunggulan relatif jika dibandingkan Fisher dan Tornqvist Index, yaitu:

1) Tidak memerlukan asumsi maksimalisasi keuntungan atau minimalisasi biaya.

2) Tidak memerlukan harga input dan output.

3) Jika penelitian menggunakan data panel maka perubahan produktivitas dapat diuraikan menjadi dua komponen, yaitu perubahan efisiensi teknis dan perubahan teknis.

\section{Efisiensi dan Produktivitas Asuransi Syariah}

Efisiensi dan produktivitas merupakan ukuran-ukuran yang menunjukkan kinerja suatu entitas/perusahaan dan merupakan rasio dari hubungan input dan output. Sehingga efisiensi dan produktivitas dapat dioptimalkan dengan cara melakukan penyesuaian pada sisi input atau output atau bahkan keduanya (Rusydiana, 2018).

Metode yang digunakan dalam penelitian ini untuk mengukur efisiensi perusahaan asuransi syariah yaitu pendekatan nonparametrik Data Envelopment Analysis (DEA). DEA merupakan metode yang paling banyak digunakan untuk pengukuran efisiensi lembaga keuangan (termasuk asuransi syariah) dan lembaga nonkeuangan. Penelitian ini menggunakan pengukuran efisiensi berorientasi output karena kondisi pasar saat ini masih bagus yang terlihat dari data pertumbuhan asuransi syariah masih terjadi setiap tahunnya serta potensi untuk mengembangkan asuransi syariah masih cukup besar.

Penelitian-penelitian efisiensi pada asuransi syariah telah dilakukan di beberapa negara yang menganut sistem ganda untuk industri asuransinya, termasuk di Indonesia. Kader et al. (2010) melakukan penelitian tentang tingkat efisiensi biaya serta faktor-faktor yang memengaruhi efisiensi asuransi syariah di sepuluh negara. Hasil penelitian tersebut di antaranya menunjukkan bahwa perusahaan asuransi syariah yang lebih besar memiliki tingkat efisiensi yang lebih baik. Al-Amri (2015) melakukan penelitian tingkat efisiensi asuransi syariah di negara-negara GCC (Gulf Cooperation Council) untuk periode data tahun 2004-2009. Penelitiannya menyimpulkan bahwa perusahaan-perusahaan asuransi syariah di negera GCC memiliki rata-rata tingkat efisiensi teknis (technical efficiency) yang tinggi, sedangkan rata-rata efisiensi biayanya (cost efficiency) berada pada level moderat.

Beberapa penelitian untuk membandingkan tingkat efisiensi antara asuransi syariah dengan asuransi konvensional telah dilakukan di beberapa negara seperti penelitian Saad (2012) dan Antonio et al. (2013) untuk kasus di Malaysia. Khan \& Noreen (2014) serta Taib et al. (2018) yang mengambil kasus di Pakistan. Hidayat \& Abdulla (2015) pada industri asuransi di Bahrain. Akhtar (2018) serta Benyoussef \& Hemrit (2019) yang melakukan penelitian pada perusahaan asuransi di Saudi Arabia. Hasil penelitian-penelitian ini mayoritas menunjukkan bahwa rata-rata tingkat efisiensi asuransi konvensional lebih baik dibandingkan rata-rata tingkat efisiensi asuransi syariah. Hasil yang berbeda diperoleh dari penelitian Khan \& Noreen (2014) yang menyatakan bahwa tingkat efisiensi perusahaan asuransi syariah lebih baik dibandingkan tingkat efisiensi asuransi konvensional. 
Penelitian tingkat efisiensi asuransi syariah di Indonesia juga sudah dilakukan namun jumlahnya masih sedikit. Benarda et al. (2016) melakukan penelitian tingkat efisiensi industri asuransi jiwa syariah selama periode 2011-2014 dan hasilnya menunjukkan bahwa rata-rata tingkat efisiensi perusahaan asuransi jiwa syariah selama periode tersebut belum efisien.

Sabiti et al. (2017) melakukan penelitian tingkat efisiensi asuransi jiwa syariah dan asuransi umum syariah dengan mengambil sampel 14 perusahaan asuransi jiwa syariah dan 12 perusahaan asuransi umum syariah untuk periode data 2013-2015. Penelitian ini menunjukkan hasil bahwa baik pada perusahaan asuransi jiwa syariah maupun perusahaan asuransi umum syariah belum beroperasi secara efisien.

Sunarsih \& Fitriyani (2018) meneliti tentang analisis efisiensi asuransi syariah di Indonesia tahun 2014-2016 dengan jumlah sampel sebanyak 17 perusahaan yang terdiri dari 9 perusahaan asuransi umum syariah dan 8 perusahaan asuransi jiwa syariah. Penelitian ini menyimpulkan bahwa perusahaan asuransi syariah yang tidak efisien dipengaruhi oleh beberapa faktor, yaitu beban umum dan administrasi, pembayaran klaim, pendapatan investasi, penanaman modal, serta penghimpunan dana tabarru'.

Pengukuran produktivitas dilakukan untuk menilai kinerja perusahaan. Pengukuran produktivitas dalam penelitian ini adalah pengukuran TFP menggunakan Mamlquist Productivity Index (MPI). Mamlquist Productivity Index (MPI) merupakan metode yang banyak digunakan untuk melakukan analisis produktivitas perusahaan.

Produktivitas erat kaitannya dengan efisiensi dan salah satu komponen dalam pengukuran tingkat produktivitas yaitu perubahan efisiensi. Oleh karena itu, umumnya penelitian-penelitian tentang analisis produktivitas dikombinasikan juga dengan analisis efisiensi menggunakan variabel-variabel input dan output yang sama, di antaranya penelitian Cummins \& Xie (2013), Chakraborty et al. (2013), Yaisawarng et al. (2014), Bienera et al. (2015), Noreen \& Ahmad (2016), Viverita et al. (2016) serta Suryoaji \& Cahyono (2019).

Beberapa penelitian tentang produktivitas perusahaan asuransi di Indonesia telah dilakukan. Majid et al. (2017) melakukan penelitian pada 9 perusahaan asuransi di Indonesia yang terdaftar di Bursa Efek Indonesia untuk periode data 2012-2015. Hasil penelitian ini menyimpulkan bahwa untuk meningkatkan tingkat produktivitas maka manajer perusahaan asuransi harus secara selektif menggabungkan input yang ada untuk menghasilkan output dengan penggunaan biaya yang paling rendah dan penggunaan teknologi yang canggih. Selain itu, penelitian ini juga menunjukkan bahwa perusahaan skala kecil memiliki tingkat produktivitas yang lebih rendah dibandingkan perusahaan yang lebih besar.

Viverita et al. (2016) melakukan penelitian tentang analisis terhadap efisiensi biaya dan produktivitas industri asuransi di Indonesia dengan menggunakan sampel sebanyak 118 perusahaan asuransi yang terdiri dari 35 perusahaan asuransi jiwa dan perusahaan asuransi kerugian selama periode 2006-2008. Hasil penelitian menunjukkan bahwa pada periode tersebut perusahaan asuransi secara rata-rata mengalami pertumbuhan produktivitas yang disebabkan oleh peningkatan penggunaan teknologi yang canggih.

Suryoaji \& Cahyono (2019) melakukan penelitian untuk menganalisis perbandingan efisiensi dan produktivitas antara asuransi jiwa konvensional dengan asuransi jiwa syariah. Penelitian ini dilakukan terhadap 29 perusahaan yang terdiri dari 19 perusahaan asuransi jiwa konvensional dan 10 perusahaan asuransi jiwa syariah. Hasil penelitian ini menunjukkan bahwa secara rata-rata tingkat produktivitas asuransi jiwa konvensional mengalami kenaikkan sedangkan tingkat produktivitas asuransi jiwa syariah mengalami penurunan. 


\section{METODE}

Penelitian ini menggunakan pendekatan deskriptif yaitu untuk menggambarkan tingkat efisiensi dan produktivitas industri asuransi syariah di Indonesia. Pengukuran tingkat efisiensi menggunakan pendekatan nonparametrik menggunakan metode Data Envelopment Analysis (DEA). Tingkat produktivitas yang diukur adalah Total Factor Productivity (TFP) menggunakan Malmquist Productivity Index dengan metode DEA. Selain itu, dalam penelitian ini juga menganalisis faktorfaktor yang memengaruhi tingkat efisiensi asuransi syariah dengan menggunakan metode regresi Tobit.

Data yang digunakan dalam penelitian ini adalah data sekunder yang berasal dari laporan keuangan tahunan publikasi masing-masing perusahaan asuransi syariah dengan periode data tahun 2016-2018. Penelitian ini dilakukan terhadap 26 perusahaan asuransi jiwa syariah dan 22 perusahaan asuransi umum syariah. Penggunaan jumlah sampel sebanyak 48 perusahaan karena atas perusahaanperusahaan tersebut dapat diperoleh data yang lengkap untuk periode tahun 2016-2018. Beberapa perusahaan yang tidak masuk dalam sampel penelitian ini karena tidak diperoleh data lengkap untuk periode tahun 2016-2018.

Software yang digunakan dalam penelitian ini yaitu MaxDEA 6 untuk mengukur tingkat efisiensi, EViews 6 untuk menganalisis faktor-faktor yang memengaruhi efisiensi, dan software DEAP 2.1 digunakan untuk mengukur tingkat produktivitas. Variabel-variabel input dalam penelitian ini terdiri dari ekuitas, beban usaha dan klaim. Sedangkan variabel-variabel output dalam penelitian ini terdiri dari kontribusi (premi) dan nilai investasi. Pemilihan variabel input dan output dalam penelitian ini mengacu pada penelitian yang dilakukan oleh Taib et al. (2018).

\section{Data Envelopment Analysis (DEA)}

Data Envelopment Analysis (DEA) pertama kali diperkenalkan oleh Charnes, Cooper, dan Rhodes pada tahun 1978. DEA adalah suatu teknik pemrograman matematika yang mengukur tingkat efisiensi Unit Pembuat Keputusan/UPK dengan mengevaluasi kinerja/nilai dari input dan ouput yang telah ditetapkan seragam untuk masing-masing UPK tersebut. Analisis yang dilakukan berdasarkan kepada evaluasi terhadap efisiensi relatif dari UPK yang sebanding. Selanjutnya UPK-UPK yang efisien tersebut akan membentuk garis frontier. Jika UPK berada pada garis frontier, maka UPK tersebut dapat dikatakan efisien relatif dibandingkan dengan UPK yang lain dalam grupnya. Nilai efisiensi dari DEA berkisar antara 0 sampai dengan 1 . Nilai 1 menunjukkan hasil yang efisien sedangkan nilai yang semakin rendah menujukkan semakin tidak efisien. Selain menghasilkan nilai efisiensi masing-masing UPK, DEA juga menunjukkan unit-unit yang menjadi referensi bagi unit-unit yang tidak efisien. Model matematis dari DEA digambarkan sebagai berikut (Ascarya et al., 2010):

Efficiency of UPK $K_{j}=\frac{\sum_{k=1}^{p} \mu_{k} \cdot y_{k j}}{\sum_{i=1}^{m} \mu_{i} \cdot x_{i j}}$

Keterangan :

$\mathrm{m}=$ jumlah variabel input

$\mathrm{p}=$ jumlah variabel output

$x_{i j}=$ nilai dari input $\mathrm{i}$ dari UPKj

$y_{k j}=$ nilai dari output $\mathrm{k}$ dari $\mathrm{UPKj}$

$j=1,2, \ldots$, n dengan $n=$ jumlah UPK yang diteliti

Terdapat dua model yang sering digunakan dalam pendekatan DEA ini, yaitu Constant Return to Scale (CRS) dan Variable Return to Scale (VRS). Model Constant Return to Scale dikembangkan oleh Charnes, Cooper dan Rhodes pada tahun 1978 sehingga dikenal dengan nama model CCR. Model ini mengasumsikan bahwa rasio antara penambahan input dan output adalah sama. Artinya, jika ada tambahan input sebesar $x$ kali, maka output akan meningkat sebesar $x$ kali juga. Asumsi lain yang digunakan dalam model ini adalah bahwa setiap perusahaan atau unit pembuat keputusan (UPK) 
beroperasi pada skala yang optimal.

Model Variable Return to Scale dikembangkan oleh Banker, Charnes, dan Cooper pada tahun 1984, sehingga model ini dinamai juga model BCC. Model ini merupakan pengembangan dari model CCR. Model ini beranggapan bahwa perusahaan tidak atau belum beroperasi pada skala yang optimal. Asumsi dari model ini adalah bahwa rasio antara penambahan input dan output tidak sama. Artinya, penambahan input sebesar $x$ kali tidak akan menyebabkan output meningkat sebesar $x$ kali, bisa lebih kecil atau lebih besar dari $x$ kali.

\section{Regresi Tobit}

Model regresi tobit pertama kali disampaikan oleh James Tobin pada tahun 1958. Tobin membentuk model ini dengan melakukan pengembangan dari model probit, sehingga model ini dinamakan model Tobit. Model Tobit digunakan untuk menganalisis pengaruh variabel-variabel bebas (independent) terhadap variabel tidak bebas (dependent) dengan ketentuan variabel tidak bebas tersebut nilainya terbatas atau sengaja dibatasi (censored) sedangkan variabel tidak bebas nilainya tidak terbatas/dibatasi.

Analisis lanjutan untuk mengukur pengaruh beberapa variabel bebas yang dipilih terhadap tingkat efisiensi relatif asuransi syariah menggunakan model regresi Tobit menjadi tepat. Hal ini karena nilai efisiensi relatif asuransi syariah nilainya terbatas yaitu dari 0 sampai dengan 1 . Analisis lanjutan menggunakan model regresi Tobit dilakukan setelah nilai efisiensi relatif menggunakan metode DEA diperoleh, sehingga analisis ini disebut juga analisis Two-stage DEA.

Penggunaan model regresi Tobit untuk menganalisis faktor-faktor yang memengaruhi efisiensi relatif telah banyak digunakan dalam penelitian-penelitian sebelumnya, baik pada penelitian dalam bidang asuransi maupun dalam bidang lain seperti perbankan. Beberapa penelitian yang menggunakan regresi Tobit untuk menganalisis faktor-faktor yang memengaruhi efisiensi relatif pada perusahaan asuransi di antaranya penelitian yang dilakukan oleh Yakob et al. (2014), Benarda et al. (2016), Sabiti et al. (2017).

Penelitian ini menguji pengaruh variabel size (ukuran) perusahaan yang diwakili oleh nilai aset. Selain variabel size, penelitian ini juga menguji pengaruh variabel tingkat solvabilitas dana tabarru' dan variabel dummy type (jenis) perusahaan asuransi syariah. Persamaan regresi Tobit yang digunakan dalam penelitian ini adalah sebagai berikut:

$E_{i, t}=\beta_{1}+\beta_{2} x_{i, t}+\beta_{3} y_{i, t}+\beta_{4} z_{i, t}+\varepsilon_{i, t}$

Keterangan:

$E_{i, t}=$ tingkat efisiensi relatif perusahaan asuransi syariah

$x_{i, t}=$ variabel size (ukuran) perusahaan asuransi syariah

$y_{i, t}=$ variabel dummy type (jenis) perusahaan asuransi syariah

$z_{i, t}=$ variabel tingkat solvabilitas dana tabarru' perusahaan asuransi syariah

$\beta_{1}=$ konstanta dan $\beta_{2} \ldots \beta_{4}=$ koefisien dari variabel independen

$\varepsilon_{i, t}=$ nilai residu

\section{Malmquist Productivity Index (MPI)}

Malmquist Productivity Index (MPI) merupakan metode dengan pendekatan nonparametrik untuk mengukur produktivitas yang diperkenalkan oleh Caves et al. (1982) dan merupakan hasil pengembangan Malmquist Index yang dibuat oleh Sten Malmquist pada tahun 1953. Caves et al. (1982) mendefinisikan Malmquist Productivity Index dengan persamaan berikut: 
$M_{0}\left(x^{t+1}, y^{t+1}, x^{t}, y^{t}\right)=\left[\left(\frac{D_{0}^{t}\left(x^{t+1}, y^{t+1}\right)}{D_{0}^{t}\left(x^{t}, y^{t}\right)}\right)\left(\frac{D_{0}^{t+1}\left(x^{t+1}, y^{t+1}\right)}{D_{0}^{t+1}\left(x^{t}, y^{t}\right)}\right)\right]^{1 / 2}$

Fungsi $D_{0}$ menujukkan fungsi jarak antara input $x$ dan output $y$. Sedangkan nilai $M_{0}$ merupakan nilai Malmquist Productivity Index yang diperoleh. Nilai MPI lebih dari 1 menujukkan terjadi peningkatan produktivitas. Persamaan (3) di atas dapat dituliskan dalam bentuk persamaan lain sebagai berikut:

$M\left(x^{t+1}, y^{t+1}, x^{t}, y^{t}\right)=\left(\frac{D_{0}^{t+1}\left(x^{t+1}, y^{t+1}\right)}{D_{0}^{t}\left(x^{t}, y^{t}\right)}\right) \times\left[\left(\frac{D_{0}^{t}\left(x^{t+1}, y^{t+1}\right)}{D_{0}^{t+1}\left(x^{t+1}, y^{t+1}\right)}\right)\left(\frac{D_{0}^{t}\left(x^{t}, y^{t}\right)}{D_{0}^{t+1}\left(x^{t}, y^{t}\right)}\right)\right]^{\frac{1}{2}}$

Keterangan:

$\left(\frac{D_{0}^{t+1}\left(x^{t+1}, y^{t+1}\right)}{D_{0}^{t}\left(x^{t}, y^{t}\right)}\right)$ menunjukkan perubahan efisiensi

$\left[\left(\frac{D_{0}^{t}\left(x^{t+1}, y^{t+1}\right)}{D_{0}^{t+1}\left(x^{t+1}, y^{t+1}\right)}\right)\left(\frac{D_{0}^{t}\left(x^{t}, y^{t}\right)}{D_{0}^{t+1}\left(x^{t}, y^{t}\right)}\right)\right]^{1 / 2}$ menunjukkan perubahan teknis

Perubahan efisiensi menunjukkan perubahan efisiensi antara selama periode $t$ ke $t+1$. Nilai perubahan efisiensi lebih besar dari 1 artinya terjadi peningkatan efisiensi, nilai perubahan efisiensi sama dengan 1 artinya tidak ada perubahan efisiensi, sedangkan jika nilainya kurang dari 1 artinya terjadi penurunan efisiensi. Perubahan teknis mencerminkan perubahan teknologi atau inovasi selama periode $t$ ke $t+1$. Seperti halnya perubahan efisiensi, nilai perubahan teknis lebih besar dari 1, sama dengan 1 atau kurang dari 1 masing-masing menujukkan peningkatan teknologi/inovasi, tidak terdapat perubahan dan terjadi penurunan teknologi/inovasi.

\section{PEMBAHASAN}

\section{Efisiensi Relatif Industri Asuransi Syariah}

Metode DEA yang digunakan untuk pengukuran efisiensi dalam penelitian ini mengukur nilai Efisiensi Teknis (Technical Efficiency (TE)), Efisiensi Teknis Murni (Pure Technical Efficiency (PTE)) dan Efisiensi Skala (Scale Efficiency). Efisiensi Teknis (TE) merupakan nilai efisiensi yang diukur menggunakan model Constant Return to Scale (CRS), sedangkan Efisiensi Teknis Murni (PTE) merupakan nilai efisiensi dengan model Variable Return to Scale (VRS). Efisiensi Skala merupakan hasil dari perbandingan antara nilai efisiensi model CRS dengan nilai efisiensi model VRS. Nilai efisiensi relatif berkisar 0 sampai dengan 1. Jika nilai efisiensi relatifnya 0 maka dapat dikatakan perusahaan tidak efisien, sedangkan jika nilai efisiensi relatifnya 1 maka merupakan perusahaan yang paling efisien. Perusahaan yang nilai efisiensi relatifnya 1 menunjukkan bahwa perusahaan dapat mengoptimalkan perolehan output dengan penggunaan input yang ada. Hasil pengukuran nilai efisiensi relatif untuk masing-masing perusahaan asuransi jiwa syariah selama periode 2016 sampai dengan 2018 sebagaimana disajikan dalam Tabel 2.

Berdasarkan Tabel 2, untuk nilai Efisiensi Teknis (TE) dan Efisiensi Skala hanya satu perusahaan yang secara konsisten efisien (nilai efisiensi $=1$ ) selama periode 2016-2018 yaitu PT Great Eastern Life Indonesia Unit Syariah. Untuk nilai Efisiensi Teknis Murni (PTE) jumlah perusahaan yang konsisten efisien selama periode 2016-2018 sebanyak tiga perusahaan yaitu PT Great Eastern Life Indonesia Unit Syariah, PT AIA Financial Unit Syariah dan PT Prudential Life Assurance Unit Syariah.

Hasil pengukuran nilai efisiensi pada Tabel 2 menunjukkan bahwa perusahaan asuransi jiwa syariah yang konsisten mencapai efisien selama periode 2016-2018 semuanya merupakan unit syariah. Hal ini dapat disebabkan karena sebagian beban biaya pada unit syariah masih ditanggung oleh perusahaan induknya atau adanya sharing cost antara unit syariah dengan perusahaan induknya. Selain itu, jenis produk pada ketiga perusahaan ini mayoritas adalah produk individu unit link yang tingkat klaimnya masih cukup baik karena proses seleksi underwriting yang masih bagus pada produk individu. 
Berbeda dengan perusahaan asuransi syariah yang berbentuk full pledge, kontribusinya didominasi dari produk kumpulan seperti asuransi jiwa pembiayaan dan asuransi kesehatan yang tingkat klaimnya cukup tinggi. Tingkat klaim yang cukup tinggi pada kedua produk kumpulan ini disebabkan adanya tekanan pasar terhadap rate kontribusi serta pada ketentuan seleksi underwriting-nya.

Tabel 2 Nilai efisiensi relatif asuransi jiwa syariah tahun 2016-2018

\begin{tabular}{|c|c|c|c|c|c|c|c|c|c|}
\hline \multirow{2}{*}{$\begin{array}{l}\text { Asuransi Jiwa } \\
\text { Syariah }\end{array}$} & \multicolumn{3}{|c|}{ Efisiensi Teknis } & \multicolumn{3}{|c|}{ Efisiensi Teknis Murni } & \multicolumn{3}{|c|}{ Efisiensi Skala } \\
\hline & 2016 & 2017 & 2018 & 2016 & 2017 & 2018 & 2016 & 2017 & 2018 \\
\hline AIA & 0.956 & 1 & 0.953 & 1 & 1 & 1 & 0.959 & 1 & 0.953 \\
\hline Al Amin & 1 & 0.983 & 0.713 & 1 & 0.985 & 0.713 & 1 & 0.997 & 0.999 \\
\hline Allianz & 0.985 & 1 & 0.899 & 1 & 1 & 0.991 & 0.985 & 1 & 0.907 \\
\hline Amanah Githa & 0.441 & 0.512 & 0.417 & 0.510 & 0.604 & 0.455 & 0.864 & 0.847 & 0.917 \\
\hline Asyki & 0.403 & 0.449 & 0.497 & 0.434 & 0.496 & 0.544 & 0.929 & 0.905 & 0.914 \\
\hline Avrist & 0.494 & 0.663 & 0.344 & 0.522 & 0.712 & 0.372 & 0.946 & 0.931 & 0.924 \\
\hline AXA & 0.581 & 0.562 & 0.362 & 0.596 & 0.575 & 0.392 & 0.975 & 0.978 & 0.922 \\
\hline AXA Mandiri & 0.358 & 0.449 & 0.367 & 0.358 & 0.461 & 0.367 & 0.999 & 0.975 & 0.998 \\
\hline BNI Life & 0.953 & 0.865 & 0.832 & 0.960 & 0.918 & 0.876 & 0.993 & 0.943 & 0.950 \\
\hline BRI Life & 0.696 & 0.994 & 0.747 & 0.835 & 1 & 0.768 & 0.833 & 0.994 & 0.973 \\
\hline BumiPutera & 0.216 & 0.336 & 1 & 0.552 & 0.337 & 1 & 0.391 & 0.996 & 1 \\
\hline CAR & 0.822 & 1 & 0.251 & 0.902 & 1 & 0.309 & 0.911 & 1 & 0.814 \\
\hline Chubb Life & 0.813 & 0.624 & 0.693 & 1 & 0.747 & 0.888 & 0.813 & 0.835 & 0.780 \\
\hline FWD & 0.973 & 0.577 & 0.384 & 1 & 0.680 & 1 & 0.973 & 0.848 & 0.384 \\
\hline Great Eastern & 1 & 1 & 1 & 1 & 1 & 1 & 1 & 1 & 1 \\
\hline JMA & 0.332 & 0.645 & 0.394 & 0.394 & 0.650 & 0.401 & 0.843 & 0.993 & 0.984 \\
\hline Manulife & 0.688 & 0.757 & 0.652 & 0.697 & 0.770 & 0.673 & 0.987 & 0.983 & 0.968 \\
\hline Mega Jiwa & 0.314 & 0.900 & 0.354 & 1 & 0.920 & 0.519 & 0.314 & 0.979 & 0.683 \\
\hline Panin Life & 0.985 & 0.819 & 0.489 & 1 & 0.855 & 0.540 & 0.985 & 0.958 & 0.904 \\
\hline Prudential & 0.913 & 0.891 & 0.961 & 1 & 1 & 1 & 0.913 & 0.891 & 0.961 \\
\hline Simas Jiwa & 1 & 0.734 & 0.581 & 1 & 0.817 & 0.683 & 1 & 0.899 & 0.851 \\
\hline $\begin{array}{l}\text { Sinar Mas } \\
\text { MSIG }\end{array}$ & 0.857 & 0.852 & 1 & 0.889 & 1 & 1 & 0.964 & 0.852 & 1 \\
\hline Sun Life & 0.732 & 1 & 1 & 0.750 & 1 & 1 & 0.976 & 1 & 1 \\
\hline $\begin{array}{l}\text { Takaful } \\
\text { Keluarga }\end{array}$ & 0.932 & 1 & 0.855 & 0.944 & 1 & 0.855 & 0.987 & 1 & 0.999 \\
\hline Tokio Marine & 0.725 & 0.590 & 0.830 & 0.910 & 0.671 & 1 & 0.796 & 0.880 & 0.830 \\
\hline Wanaartha & 0.398 & 1 & 1 & 0.783 & 1 & 1 & 0.508 & 1 & 1 \\
\hline
\end{tabular}

Sumber: Output MaxDEA 6, 2019 (diolah)

Nilai rata-rata efisiensi relatif asuransi jiwa syariah selama periode tahun 2016-2018 untuk Efisiensi Teknis (TE), Efisiensi Teknis Murni (PTE) dan Efisiensi Skala masing-masing sebesar $72.24 \%$, 78.95\% dan $91.21 \%$. Tabel 3 menampilkan hasil perhitungan nilai rata-rata efisiensi relatif pada perusahaan asuransi jiwa syariah untuk masing-masing tahun 2016 sampai dengan 2018. 
Tabel 3 Nilai rata-rata efisiensi relatif asuransi jiwa syariah tahun 2016-2018

\begin{tabular}{cccc}
\hline \multirow{2}{*}{$\begin{array}{c}\text { Periode } \\
\text { (Tahun) }\end{array}$} & $\begin{array}{c}\text { Efisiensi Teknis } \\
\text { (TE) }\end{array}$ & $\begin{array}{c}\text { Efisiensi Teknis } \\
\text { Murni (PTE) }\end{array}$ & Efisiensi Skala \\
\cline { 2 - 4 } & 0.71423 & 0.80916 & 0.87862 \\
2016 & 0.77703 & 0.81532 & 0.94938 \\
2017 & 0.67593 & 0.74414 & 0.90826 \\
\hline
\end{tabular}

Sumber: Output MaxDEA 6, 2019 (diolah)

Nilai pada Tabel 3 menujukkan bahwa pada asuransi jiwa syariah memiliki tren yang sama baik untuk Efisiensi Teknis (TE), Efisiensi Teknis Murni (PTE) maupun Efisiensi Skala yaitu nilai rata-rata efisiensi relatif mengalami kenaikkan pada tahun 2017 dan mengalami penurunan di tahun 2018.

Jumlah Unit Pembuat Keputusan (UPK) pada asuransi jiwa syariah dalam penelitian ini sebanyak 78 yang merupakan jumlah data panel dari 26 perusahaan untuk periode tiga tahun, 2016 sampai dengan 2018. Jumlah UPK pada asuransi jiwa syariah yang mencapai efisien selama periode tahun 2016-2018 untuk Efisiensi Teknis (TE) dan Efisiensi Skala sebanyak 15 UPK, untuk Efisiensi Teknis Murni (PTE) sebanyak 29 UPK.

Tabel 4 Distribusi nilai efisiensi relatif asuransi jiwa syariah tahun 2016-2018

\begin{tabular}{lccc}
\hline $\begin{array}{l}\text { Nilai Efisiensi } \\
\text { Relatif }\end{array}$ & $\begin{array}{c}\text { Efisiensi Teknis } \\
\text { (TE) }\end{array}$ & $\begin{array}{c}\text { Efisiensi Teknis } \\
\text { Murni (PTE) }\end{array}$ & Efisiensi Skala \\
\hline 1 & 15 & 29 & 15 \\
$0.50000-0.99999$ & 42 & 37 & 60 \\
$0.00001-0.49999$ & 21 & 12 & 3 \\
\hline Total & 78 & 78 & 78 \\
\hline
\end{tabular}

Sumber: Output MaxDEA 6, 2019 (diolah)

Berdasarkan Tabel 4, persentase jumlah UPK yang mencapai efisien (nilai efisiensi relatifnya $=1$ ) baik untuk Efisiensi Teknis (TE), Efisiensi Teknis Murni (PTE) maupun Efisiensi Skala masih kurang dari 50\%. Hasil ini menunjukkan bahwa mayoritas UPK masih belum efisien selama periode 20162018.

Hasil perhitungan efisiensi relatif untuk masing-masing perusahaan asuransi umum syariah sebagaimana ditampilkan pada Tabel 5. Berdasarkan nilai pada Tabel 5, untuk nilai Efisiensi Teknis (TE) dan Efisiensi Skala terdapat dua perusahaan yang konsisten efisien selama periode 2016-2018, yaitu PT Asuransi Adira Dinamika Unit Syariah dan PT Asuransi Wahana Tata Unit Syariah. Untuk nilai Efisiensi Teknis Murni (PTE) sebanyak lima perusahaan konsisten efisien selama periode 20162018 yaitu PT Asuransi Adira Dinamika Unit Syariah, PT Asuransi Astra Buana Unit Syariah, PT Bringin Sejahtera Artamakmur (BRINS General) Unit Syariah, PT Asuransi Kresna Mitra Unit Syariah, dan PT Asuransi Wahana Tata Unit Syariah.

Seperti pada asuransi jiwa syariah, perusahaan-perusahaan asuransi umum syariah yang konsisten beroperasi secara efisien selama periode 2016-2018 seluruhnya merupakan unit syariah. Kondisi ini dapat disebabkan karena sebagian beban biaya pada unit syariah masih ditanggung oleh perusahaan induknya atau adanya sharing cost antara unit syariah dengan perusahaan induknya. Selain itu, produksi/kontribusi (premi) yang diperoleh perusahaan-perusahaan ini berasal dari produk-produk yang tingkat klaimnya cukup rendah, sebagaimana terlihat pada laporan keuangan masing-masing perusahaan yaitu diperolehnya surplus underwriting selama periode 2016-2018. 
Tabel 5 Nilai efisiensi relatif asuransi umum syariah tahun 2016-2018

\begin{tabular}{|c|c|c|c|c|c|c|c|c|c|}
\hline \multirow{2}{*}{$\begin{array}{c}\text { Asuransi } \\
\text { Umum } \\
\text { Syariah }\end{array}$} & \multicolumn{3}{|c|}{ Efisiensi Teknis } & \multicolumn{3}{|c|}{ Efisiensi Teknis Murni } & \multicolumn{3}{|c|}{ Efisiensi Skala } \\
\hline & 2016 & 2017 & 2018 & 2016 & 2017 & 2018 & 2016 & 2017 & 2018 \\
\hline ACA Syariah & 0.608 & 0.598 & 0.691 & 0.613 & 0.604 & 0.709 & 0.992 & 0.991 & 0.975 \\
\hline Adira Syariah & 1 & 1 & 1 & 1 & 1 & 1 & 1 & 1 & 1 \\
\hline ASEI Syariah & 1 & 0.532 & 1 & 1 & 0.611 & 1 & 1 & 0.871 & 1 \\
\hline $\begin{array}{l}\text { Askrida } \\
\text { Syariah }\end{array}$ & 0.926 & 1 & 0.875 & 0.937 & 1 & 1 & 0.988 & 1 & 0.875 \\
\hline Astra Syariah & 1 & 0.9851 & 0.983 & 1 & 1 & 1 & 1 & 0.985 & 0.983 \\
\hline $\begin{array}{l}\text { AXA General } \\
\text { Syariah }\end{array}$ & 1 & 1 & 0.912 & 1 & 1 & 0.926 & 1 & 1 & 0.986 \\
\hline $\begin{array}{l}\text { BRINS } \\
\text { Syariah }\end{array}$ & 0.997 & 0.768 & 1 & 1 & 1 & 1 & 0.997 & 0.768 & 1 \\
\hline $\begin{array}{l}\text { Bumida } \\
\text { Syariah }\end{array}$ & 0.715 & 0.657 & 0.872 & 0.726 & 1 & 0.991 & 0.985 & 0.657 & 0.880 \\
\hline Chubb Syariah & 0.646 & 0.692 & 0.743 & 0.717 & 0.744 & 0.790 & 0.902 & 0.930 & 0.940 \\
\hline $\begin{array}{l}\text { Jasaraharja } \\
\text { Putera Syariah }\end{array}$ & 0.699 & 0.854 & 0.806 & 0.720 & 0.928 & 0.809 & 0.970 & 0.920 & 0.995 \\
\hline $\begin{array}{l}\text { Jasindo } \\
\text { Takaful }\end{array}$ & 0.735 & 0.821 & 0.564 & 0.760 & 0.858 & 0.569 & 0.967 & 0.957 & 0.990 \\
\hline $\begin{array}{l}\text { Kresna Mitra } \\
\text { Syariah }\end{array}$ & 1 & 0.976 & 0.946 & 1 & 1 & 1 & 1 & 0.976 & 0.946 \\
\hline $\begin{array}{l}\text { Mega Umum } \\
\text { Syariah }\end{array}$ & 0.921 & 0.904 & 0.776 & 0.973 & 1 & 0.981 & 0.947 & 0.904 & 0.791 \\
\hline $\begin{array}{l}\text { Pan Pacifik } \\
\text { Syariah }\end{array}$ & 0.912 & 0.862 & 0.858 & 0.989 & 0.951 & 0.918 & 0.923 & 0.906 & 0.935 \\
\hline $\begin{array}{l}\text { Parolamas } \\
\text { Syariah }\end{array}$ & 0.991 & 1 & 0.560 & 1 & 1 & 0.564 & 0.991 & 1 & 0.994 \\
\hline $\begin{array}{l}\text { Ramayana } \\
\text { Syariah }\end{array}$ & 1 & 0.351 & 0.544 & 1 & 0.352 & 0.701 & 1 & 0.999 & 0.776 \\
\hline $\begin{array}{l}\text { Reliance } \\
\text { Syariah }\end{array}$ & 1 & 0.873 & 0.676 & 1 & 0.976 & 0.787 & 1 & 0.895 & 0.860 \\
\hline $\begin{array}{l}\text { Sinarmas } \\
\text { Syariah }\end{array}$ & 1 & 0.881 & 1 & 1 & 0.949 & 1 & 1 & 0.929 & 1 \\
\hline $\begin{array}{l}\text { Sonwelis } \\
\text { Takaful }\end{array}$ & 0.431 & 0.527 & 0.396 & 0.512 & 0.781 & 0.603 & 0.842 & 0.675 & 0.657 \\
\hline TPI Syariah & 1 & 0.807 & 0.635 & 1 & 0.807 & 0.644 & 1 & 0.999 & 0.986 \\
\hline $\begin{array}{l}\text { Tri Pakarta } \\
\text { Syariah }\end{array}$ & 0.804 & 0.928 & 0.794 & 0.831 & 0.928 & 0.797 & 0.966 & 0.999 & 0.997 \\
\hline $\begin{array}{l}\text { Wahana Tata } \\
\text { Syariah }\end{array}$ & 1 & 1 & 1 & 1 & 1 & 1 & 1 & 1 & 1 \\
\hline
\end{tabular}

Sumber: Output MaxDEA 6, 2019 (diolah) 
Nilai rata-rata efisiensi relatif asuransi umum syariah selama periode tahun 2016-2018 untuk Efisiensi Teknis (TE), Efisiensi Teknis Murni (PTE) dan Efisiensi Skala masing-masing sebesar 83.39\%, $87.96 \%$ dan $94.54 \%$. Nilai rata-rata efisiensi relatif asuransi umum syariah untuk masing-masing tahun 2016 sampai dengan 2018 sebagaimana tercantum pada Tabel 6.

Tabel 6 Nilai rata-rata efisiensi relatif asuransi umum syariah tahun 2016-2018

\begin{tabular}{cccc}
\hline \multirow{2}{*}{ Periode (Tahun) } & \multicolumn{3}{c}{ Nilai Rata-Rata Efisiensi Relatif } \\
\cline { 2 - 4 } & $\begin{array}{c}\text { Efisiensi Teknis } \\
\text { (TE) }\end{array}$ & $\begin{array}{c}\text { Efisiensi Teknis Murni } \\
\text { (PTE) }\end{array}$ & $\begin{array}{c}\text { Efisiensi } \\
\text { Skala }\end{array}$ \\
\hline 2016 & 0.88119 & 0.89904 & 0.97592 \\
2017 & 0.81894 & 0.88586 & 0.92553 \\
2018 & 0.80146 & 0.85403 & 0.93479 \\
\hline
\end{tabular}

Sumber: Output MaxDEA 6, 2019 (diolah)

Berbeda dengan asuransi jiwa syariah, berdasarkan Tabel 6 terlihat bahwa nilai rata-rata efisiensi asuransi umum syariah mengalami penurunan dari periode tahun 2016 sampai dengan 2018. Penurunan terjadi pada ketiga jenis efisiensi yaitu Efisiensi Teknis (TE), Efisiensi Teknis Murni (PTE) maupun Efisiensi Skala.

Jumlah Unit Pembuat Keputusan (UPK) pada asuransi umum syariah dalam penelitian ini sebanyak 66. Sebaran dari jumlah UPK tersebut yang mencapai efisien pada asuransi umum syariah selama periode tahun 2016-2018 sebagaimana tercantum pada Tabel 7.

Tabel 7 Distribusi nilai efisiensi relatif asuransi umum syariah tahun 2016-2018

\begin{tabular}{lccc}
\hline $\begin{array}{c}\text { Nilai Efisiensi } \\
\text { Relatif }\end{array}$ & $\begin{array}{c}\text { Efisiensi Teknis } \\
\text { (TE) }\end{array}$ & $\begin{array}{c}\text { Efisiensi Teknis } \\
\text { Murni (PTE) }\end{array}$ & Efisiensi Skala \\
\hline 1 & 20 & 30 & 20 \\
$0.50000-0.99999$ & 43 & 35 & 46 \\
$0.00001-0.49999$ & 3 & 1 & 0 \\
\hline Total & 66 & 66 & 66 \\
\hline
\end{tabular}

Sumber : Output MaxDEA 6, 2019 (diolah)

Seperti halnya pada asuransi jiwa syariah, mayoritas UPK pada asuransi umum syariah belum efisien selama periode tahun 2016-2018. Berdasarkan Tabel 7, persentase jumlah UPK yang efisien untuk Efisiensi Teknis Murni (PTE) sebesar 45.45\% sedangkan untuk Efisiensi Teknis (TE) dan Efisiensi Skala sebesar $30.30 \%$.

\section{Analisis Return to Scale}

Perhitungan efisiensi menggunakan metode DEA menampilkan juga hasil analisis return to scale untuk masing-masing UPK. Analisis return to scale dilakukan untuk melihat berapa banyak perusahaan asuransi jiwa syariah atau asuransi umum syariah yang termasuk ke dalam kondisi Increasing Return to Scale (IRS), Constant Return to Scale (CRS) maupun Decreasing Return to Scale (DRS). Suatu perusahaan yang berada dalam kondisi IRS artinya perusahaan tersebut masih memungkinkan untuk menaikkan kapasitas outputnya dengan menggunakan input yang ada, sedangkan perusahaan dengan kondisi DRS harus mengurangi input untuk meningkatkan efisiensinya. Adapun perusahaan yang termasuk kedalam kondisi CRS maka perusahaan tersebut sudah dalam kondisi efisien.

Hasil perhitungan analisis return to scale pada asuransi jiwa menunjukkan bahwa sebanyak 33 UPK dalam kondisi IRS, 30 UPK dalam kondisi DRS dan sisanya dalam kondisi CRS. Apabila dilihat trennya selama periode pengamatan tahun 2016-2018, menujukkan bahwa jumlah UPK dalam kondisi 
IRS dan CRS cenderung mengalami kenaikan dari tahun 2016 sampai tahun 2018, sedangkan jumlah UPK yang dalam kondisi DRS cenderung mengalami penurunan (Gambar 1).

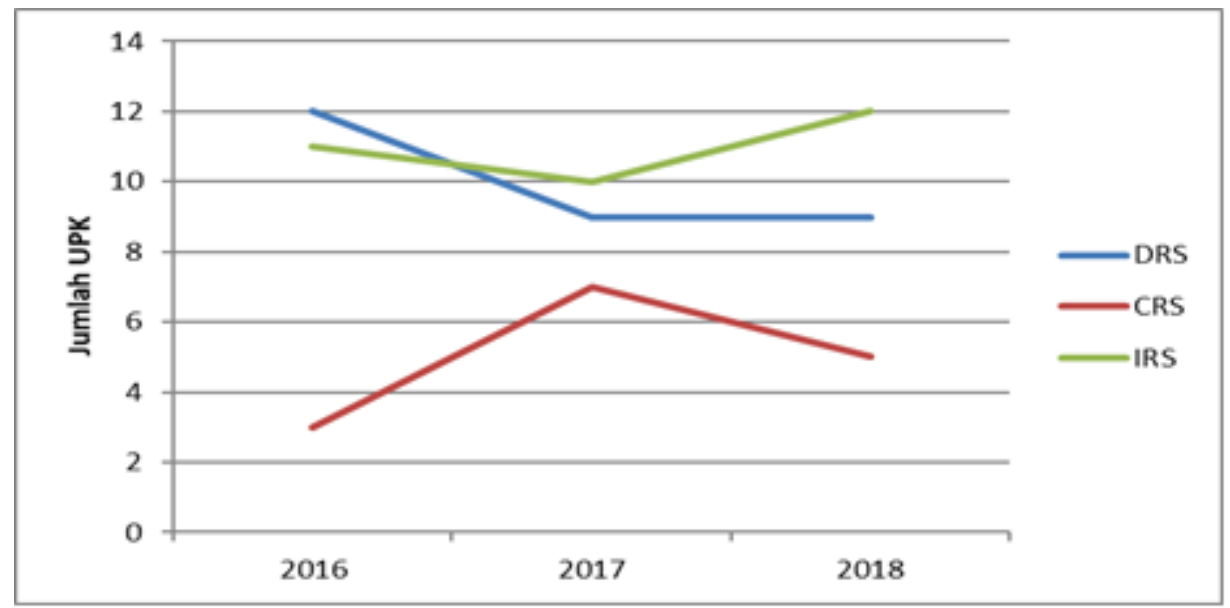

Sumber: Output MaxDEA 6, 2019 (diolah)

Gambar 1 Tren analisis return to scale asuransi jiwa syariah

Gambar 2 menampilkan hasil analisis tren return to scale pada asuransi umum syariah selama periode 2016-2018. Analisis return to scale pada asuransi umum syariah menujukan bahwa sebanyak 28 UPK dalam kondisi IRS, 18 UPK dalam kondisi DRS dan sisanya dalam kondisi CRS. Tren analisis return to scale selama periode pengamatan tahun 2016 sampai dengan tahun 2018 menunjukkan bahwa jumlah UPK dalam kondisi DRS dan IRS cenderung mengalami kenaikan dari tahun 2016 sampai tahun 2018, sedangkan jumlah UPK yang dalam kondisi CRS cenderung mengalami penurunan.

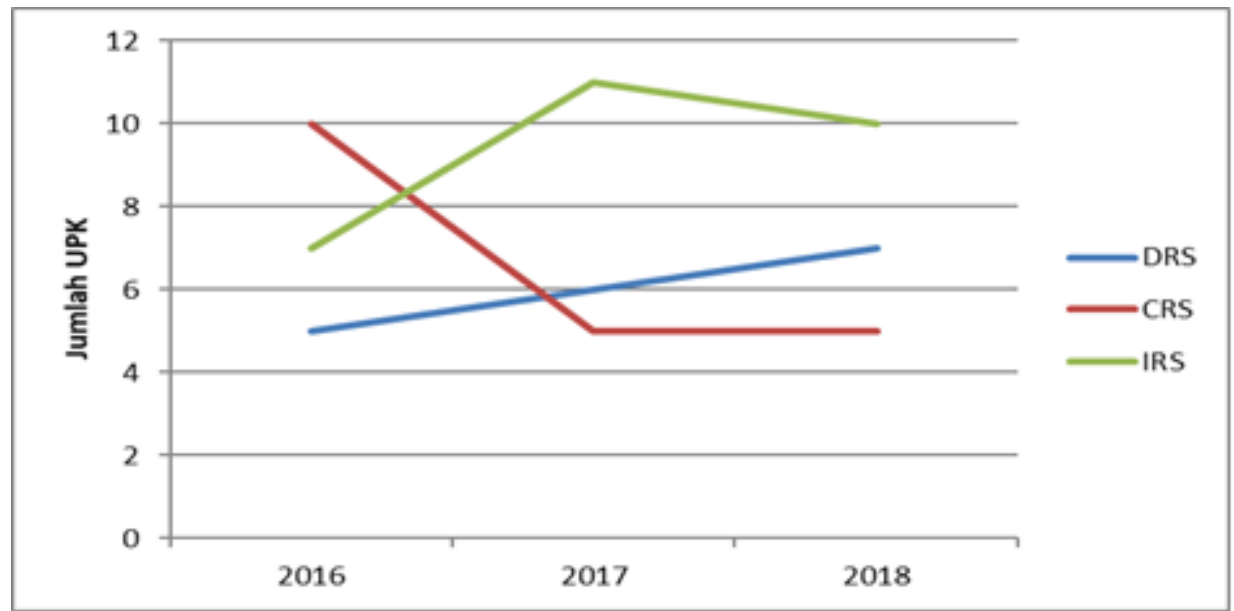

Sumber: Output MaxDEA 6, 2019 (diolah)

Gambar 2 Tren analisis return to scale asuransi umum syariah

\section{Faktor-Faktor yang Memengaruhi Efisiensi Asuransi Syariah}

Analisis faktor-faktor yang memengaruhi tingkat efisiensi asuransi jiwa syariah maupun asuransi umum syariah menggunakan persamaan (2) regresi Tobit dan dilakukan terhadap nilai Efisiensi Teknis (TE), yaitu efisiensi dengan model CRS dan nilai Efisiensi Teknis Murni (PTE), yaitu efisiensi dengan model VRS yang telah dihitung pada bagian muka di atas.

Tabel 8 menampilkan hasil pengukuran yang menunjukkan pengaruh masing-masing variabel yaitu size, type dan tingkat solvabilitas dana tabarru' terhadap nilai Efisiensi Teknis (TE). Berdasarkan hasil Tabel 8, seluruh variabel independen yang diteliti memberikan pengaruh positif terhadap nilai efisiensi teknis, hal ini sebagaimana terlihat dari nilai koefisien dari masing-masing variabel yang 166 
bernilai positif. Pengaruh dari masing-masing variabel independen terhadap variabel dependen apakah berpengaruh signifikan atau tidak dapat dilihat dari nilai Prob (p-value) nya. Hasil di atas menunjukkan hanya variabel size yang mewakili jumlah aset berpengaruh signifikan terhadap nilai Efisiensi Teknis (TE) pada tingkat signifikasi $\alpha=5 \%$ karena p-value $=0.0016<\alpha=5 \%$. Hal ini menujukkan bahwa semakin besar perusahaan yang ditunjukan dengan semakin besar jumlah asetnya, maka semakin baik nilai efisiensi teknisnya. Hasil tersebut menujukan bahwa untuk setiap kenaikan aset sebesar 1 juta, akan meningkatkan nilai efisiensi sebesar $0.0000032 \%$. Variabel type dan tingkat solvabilitas dana tabarru' tidak berpengaruh signifikan karena p-value $>\alpha=5 \%$.

Tabel 8 Hasil analisis faktor-faktor yang memengaruhi Efisiensi Teknis asuransi syariah

\begin{tabular}{ccccc}
\hline Variable & Coefficient & Std. Error & $\boldsymbol{z}$-Statistic & Prob. \\
\hline C & 0.534287 & 0.082815 & 6.451604 & 0.0000 \\
Size & $3.17 \mathrm{E}-08$ & $1.00 \mathrm{E}-08$ & 3.155151 & 0.0016 \\
Type & 0.069152 & 0.045319 & 1.525890 & 0.1270 \\
Solvab & 0.000306 & 0.000602 & 0.507514 & 0.6118 \\
\hline
\end{tabular}

Sumber: Output E-Views 6, 2019 (diolah)

Tabel 9 menampilkan hasil pengukuran yang menunjukkan pengaruh masing-masing variabel yaitu size, type dan tingkat solvabilitas dana tabarru' terhadap nilai Efisiensi Teknis Murni (PTE). Hasil pada Tabel 9 menujukkan bahwa ketiga variabel independen yang diteliti berpengaruh postitif terhadap nilai Efisiensi Teknis Murni (model VRS) perusahaan asuransi syariah. Terdapat dua variabel yang memiliki pengaruh signifikan terhadap nilai Efisiensi Teknis Murni (model VRS) untuk $\alpha=5 \%$ yaitu variabel size yang mewakili jumlah aset dengan $p$-value $=0.0045$ dan variabel type dengan $p$-value $=0.0013$.

Hasil tersebut menujukkan bahwa untuk setiap kenaikan aset sebesar 1 juta, akan meningkatkan nilai efisiensi sebesar $0.0000028 \%$. Sedangkan pada variabel type menujukan bahwa perusahaanperusahaan asuransi yang berbentuk unit syariah lebih efisien dibandingkan perusahaan asuransi syariah full pledge. Hasil perhitungan tersebut menunjukkan bahwa perusahaan yang berbentuk unit syariah memiliki nilai efisiensi relatif yang lebih tinggi sebesar $0.14 \%$ dibandingkan perusahaan syariah full pledge. Variabel tingkat solvabilitas tidak berpengaruh signifikan terhadap nilai Efisiensi Teknis Murni (model VRS).

Tabel 9 Hasil analisis faktor-faktor yang memengaruhi Efisiensi Teknis asuransi syariah

\begin{tabular}{ccccc}
\hline Variable & Coefficient & Std. Error & $\boldsymbol{z}$-Statistic & Prob. \\
\hline C & 0.493352 & 0.080574 & 6.123004 & 0.0000 \\
Size & $2.77 \mathrm{E}-08$ & $9.77 \mathrm{E}-09$ & 2.841227 & 0.0045 \\
Type & 0.141858 & 0.044093 & 3.217263 & 0.0013 \\
Solvab & 0.000136 & 0.000586 & 0.231570 & 0.8169 \\
\hline
\end{tabular}

Sumber: Output E-Views 6, 2019 (diolah)

Hasil analisis regresi Tobit baik untuk nilai Efisiensi Teknis (TE) maupun Efisiensi Teknis Murni (PTE) menunjukkan bahwa jumlah aset berpengaruh signifikan terhadap nilai efisiensi. Sehubungan dengan ketentuan pada UU No. 40 tahun 2014 pasal 87 tentang kewajiban pemisahan unit syariah (spin off) yang harus dilakukan paling lambat tahun 2024, tentunya harus dilihat kembali kesiapan masing-masing unit syariah pada tahun 2024. Apakah unit syariah yang akan melakukan pemisahan telah memiliki jumlah aset yang cukup untuk bersaing dengan asuransi konvensional.

\section{Produktivitas Industri Asuransi Syariah}

Tabel 10 menujukkan nilai rata-rata perubahan TFP pada asuransi jiwa syariah selama periode tahun 2016 sampai dengan tahun 2018. Nilai Perubahan TFP dipegaruhi oleh dua komponen yaitu perubahan efisiensi (efficiency change) serta perubahan teknologi (technological change). Perusahaan yang mengalami peningkatan produktivitas adalah perusahaan yang nilai perubahan TFP nya lebih dari 1 , sedangkan perusahaan yang nilai perubahan TFP nya kurang dari 1 mengalami penurunan 
produktivitas. Apabila nilai perubahan TFP sama dengan 1 maka perusahaan tidak mengalami perubahan produktivitas.

Tabel 10 Nilai rata-rata perubahan TFP per tahun asuransi jiwa syariah

\begin{tabular}{cccc}
\hline Periode & $\begin{array}{c}\text { Perubahan Efisiensi } \\
\text { (Efficiency Change) }\end{array}$ & $\begin{array}{c}\text { Perubahan Teknologi } \\
\text { (Technological } \\
\text { Change) }\end{array}$ & $\begin{array}{c}\text { Perubahan TFP } \\
\text { (TFP Change) }\end{array}$ \\
\hline $2016-2017$ & 0.949 & 1.043 & 0.989 \\
$2017-2018$ & 1.073 & 0.586 & 0.629 \\
Rata-rata & $\mathbf{1 . 0 0 9}$ & $\mathbf{0 . 7 8 2}$ & $\mathbf{0 . 7 8 9}$ \\
\hline
\end{tabular}

Sumber: Output DEAP 2.1, 2019 (diolah)

Hasil pada Tabel 10 menunjukkan adanya penurunan produktivitas baik untuk periode 2016-2017 maupun untuk periode 2017-2018 masing-masing sebesar $1.1 \%$ dan $37.1 \%$. Penurunan produktivitas pada periode 2016-2017 disebabkan oleh perubahan efisiensi, artinya bahwa perusahaan belum bisa menghasilkan output yang optimal menggunakan input yang tersedia. Sedangkan untuk periode 20172018, penurunan tingkat produktivitas disebabkan oleh perubahan teknologi yang berarti rendahnya tingkat penggunaan/inovasi teknologi perusahaan asuransi jiwa syariah pada periode tersebut.

Analisis produktivitas pada asuransi jiwa syariah selama periode tahun 2016-2018 menujukan bahwa secara rata-rata terjadi penurunan nilai perubahan TFP sebesar $21.1 \%$ sehingga selama periode tahun 2016-2018 tingkat produktivitas asuransi jiwa syariah secara rata-rata mengalami penurunan. Penurunan tingkat produktivitas secara rata-rata disebabkan oleh faktor penurunan perubahan teknologi.

Analisis per periode untuk perubahan TFP pada asuransi umum syariah menujukan bahwa untuk periode 2016-2017 terjadi penurunan produktivitas sebesar 8.1\% yang dipengaruhi faktor perubahan efisiensi. Sedangkan untuk periode 2017-2018 terjadi peningkatan produktivitas sebesar $42.4 \%$ yang sangat dipengaruhi oleh faktor perubahan teknologi (Tabel 11).

Tabel 11 Nilai rata-rata perubahan TFP per tahun asuransi umum syariah

\begin{tabular}{cccc}
\hline Periode & $\begin{array}{c}\text { Perubahan Efisiensi } \\
\text { (Efficiency Change) }\end{array}$ & $\begin{array}{c}\text { Perubahan Teknologi } \\
\text { (Technological } \\
\text { Change) }\end{array}$ & $\begin{array}{c}\text { Perubahan TFP } \\
\text { (TFP Change) }\end{array}$ \\
\hline $2016-2017$ & 1.008 & 0.912 & 0.919 \\
$2017-2018$ & 0.957 & 1.488 & 1.424 \\
Rata-rata & $\mathbf{0 . 9 8 2}$ & $\mathbf{1 . 1 6 5}$ & $\mathbf{1 . 1 4 4}$ \\
\hline
\end{tabular}

Sumber: Output DEAP 2.1, 2019 (diolah)

Berbeda dengan yang terjadi pada asuransi jiwa syariah, pada perusahaan-perusahaan asuransi umum syariah secara rata-rata terjadi peningkatan produktivitas selama periode 2016 sampai dengan 2018. Rata-rata nilai perubahan TFP asuransi umum syariah selama periode 2016-2018 naik sebesar $14.4 \%$. Kenaikan tersebut disebabkan adanya perubahan teknologi. Hal tersebut menunjukkan adanya inovasi teknologi pada perusahaan asuransi umum syariah.

Hasil analisis produktivitas di atas menunjukkan bahwa tingkat produktivitas asuransi jiwa syariah dan asuransi umum syariah dipengaruhi oleh faktor perubahan teknologi. Implikasi manajerial dari hasil ini yaitu agar manajemen perusahaan asuransi syariah dapat mengutamakan pengembangan sistem IT-nya serta mendorong perusahaan untuk meningkatkan inovasi baik dari sisi produk, pelayanan maupun pemasaran. Hal ini untuk mengantisipasi perkembangan teknologi yang begitu cepat serta perubahan pola bisnis yang mungkin terjadi ke depan, seperti pola pemasaran yang saat ini mulai mengarah kepada pemasaran digital. 


\section{SIMPULAN}

Perusahaan asuransi syariah di Indonesia selama periode 2016-2018 mayoritas masih belum efisien baik pada asuransi jiwa syariah maupun asuransi umum syariah, sehingga manajemen perusahaan asuransi syariah harus melakukan upaya untuk meningkatkan tingkat efisiensi, di antaranya dengan melakukan evaluasi atas penggunaan input maupun dengan mengoptimalkan pencapaian output. Perusahaan-perusahaan asuransi jiwa syariah maupun asuransi umum syariah yang konsisten beroperasi secara efisien pada periode 2016-2018 seluruhnya merupakan unit syariah. Kondisi ini disebabkan karena jumlah biaya pada unit syariah lebih rendah dibandingkan perusahaan asuransi syariah yang sudah full pledge. Selain itu, perolehan kontribusi (produksi) pada unit syariah berasal dari produk asuransi yang memiliki tingkat klaim cukup rendah.

Variabel size (ukuran) merupakan faktor yang pengaruhnya signifikan terhadap nilai Efisiensi Teknis (TE) asuransi syariah. Untuk nilai Efisiensi Teknis Murni (PTE), variabel size (ukuran) dan type (jenis) perusahaan merupakan faktor-faktor yang pengaruhnya signifikan. Faktor jumlah aset yang direpresentasikan dalam variabel size menujukkan bahwa peningkatan efisiensi asuransi syariah di antaranya dapat dilakukan dengan melakukan sinergi atau dengan melakukan merger antarperusahaan asuransi syariah yang jumlah asetnya masih kecil.

Analisis produktivitas industri asuransi syariah di Indonesia menunjukkan bahwa tingkat produktivitas perusahaan asuransi jiwa syariah selama periode 2016-2018 mengalami penurunan yang disebabkan belum optimalnya inovasi atau penggunaan teknologi pada perusahaan asuransi jiwa syariah. Sedangkan tingkat produktivitas asuransi umum syariah selama periode 2016-2018 mengalami peningkatan yang disebabkan faktor perubahan teknologi. Faktor perubahan teknologi sangat berpengaruh pada produktivitas asuransi syariah, sehingga manajemen perusahaan asuransi syariah harus mengutamakan pengembangan sistem IT-nya. Hal ini sekaligus untuk mengantisipasi perkembangan teknologi yang begitu cepat karena bukan tidak mungkin perkembangan teknologi akan mengubah pola atau proses bisnis yang saat ini berjalan.

Penelitian ini dapat dikembangkan di antaranya dengan melakukan analisis perbandingan tingkat efisiensi dan produktivitas antara asuransi syariah dengan asuransi konvensional. Sebagai pembanding, penggunaan metode lain dapat juga digunakan untuk pengukuran efisiensi dan produktivitas disebabkan setiap metode tentunya memiliki kelebihan dan kekurangannya masingmasing.

\section{DAFTAR PUSTAKA}

Akhtar, M. H. (2018). Performance analysis of takaful and conventional insurance companies in Saudi Arabia. Benchmarking: An International Journal, 25(2), 677-695.

Al-Amri, K. (2015). Takaful insurance efficiency in The GCC Coutries. Humanomics, 31(3), 344353.

Antonio, M. S. , Ali, M. M. \& Akbar, N. (2013). A comparative analysis of efficiency of takaful and conventional insurance in Malaysia. The International Journal of Excellence in Islamic Banking and Finance, 3(1), 1-13.

Ascarya \& Yumanita, D. (2006). Analisis efisiensi perbankan syariah di Indonesia dengan Data Envelopment Analysis. TAZKIA Islamic Finance and Business Review, 1(2), 1-32.

Ascarya \& Yumanita, D. (2008). Measuring the competitiveness of Islamic banking in Indonesian dual banking system. TAZKIA Islamic Finance and Business Review, 3(2), 72-89.

Ascarya, Achsani, N.A., Rokhimah, G.S. (2010). Measuring the efficiency of Islamic banks in Indonesia and Malaysia using parametric and nonparametric approaches. Center for Central Banking Education and Studies, Bank Indonesia.

Barros, C. P., Barroso, N. \& Borges, M. R. (2005). Evaluating the efficiency and productivity of insurance companies with a Malmquist Index: A case study for Portugal. The Geneva Papers on Risk and Insurance-Issues and Practice, 30(2), 244-267. 
Benarda, Sumarwan, U. \& Hosen, M. N. (2016). Tingkat efisiensi industri asuransi jiwa syariah menggunakan pendekatan two stage Data Envelopment Analysis. Jurnal Aplikasi Bisnis dan Manajemen, 2(1), 64-72.

Benyoussef, S. \& Hemrit, W. (2019). Measuring the relative efficiency of insurance companies in Saudi Arabia: The case study of takaful vs cooperative industries. Cogent Economics \& Finance, 7(1). https://doi.org/10.1080/23322039.2019.1590818.

Bienera, C., Elinga, M., Wirfs, J. H. (2015). The determinants of efficiency and productivity in the Swiss insurance industry. European Journal of Operational Research, 248(2), 703-714.

Caves, D. W., Christensen, L. R. \& Diewert, W. E. (1982). The economic theory of index number and the measurement of input, output and productivity. Econometrica: Journal of the Econometric Society, 50(6), 1393-1414.

Chakraborty, K., Dutta, A., \& Sengupta, P. P. (2013). Efficiency and productivity of Indian life insurance industry. Asia-Pacific Journal of Risk and Insurance, 7(1), 1-28.

Coelli, T. J., Rao, D. S. P., O’Donnel, C .J., \& Battese, G. E. (2005). An Introduction to Efficiency and Productivity Analysis Second Ed. New York (USA), Springer Science \& Business Media.

Cummins, J. D. \& Xie, X. (2013). Efficiency, productivity, and scale economies in the U.S. propertyliability insurance industry. Journal of Productivity Analysis, 39(2), 141-164.

Farrel, M. J. (1957). The measurement of productive efficiency. Journal of the Royal Statistical Society, 120(3), 253-281.

Hadad, M. D., Santoso, W., Ilyas, D., \& Mardanugraha, E. (2003). Analisis efisiensi industri perbankan Indonesia: Penggunaan metode nonparametrik Data Envelopment Analysis (DEA). Research Paper, no. 7/5, Biro Stabilitas Sistem Keuangan Bank Indonesia.

Hartono, I., Djohar, S., Daryanto, H.K. (2008). Analisis efisiensi Bank Perkreditan Rakyat di wilayah Jabodetabek dengan pendekatan Data Envelopment Analysis. Jurnal Manajemen dan Agribisnis, 5(2), 52-63.

Hidayat, S. E. \& Abdulla A.M. (2015). A comparative analysis on the financial performance between takaful and conventional insurance companies in Bahrain during 2006-2011. Journal of Islamic Economics. Banking and Finance, 11(2), 149-162.

Kader, H. A., Adams, M. \& Hardwick. P. (2010). The cost efficiency of takaful insurance companies. The Geneva Papers on Risk and Insurance - Issue and Practice, 35, 161-181.

Khan, A. \& Noreen, U. (2014). Efficiency measure of insurance v/s takaful firms using DEA approach : A case of Pakistan. Islamic Economic Studies, 22(1), 139-158.

Lee, H. S., Cheng, F. F., Nassir, A. M., \& Ab Razak, N.H. (2018). Does efficiency promote competitiveness of the insurance industry?. Journal of Business Economics and Management, 19(4), 566-591.

Majid, M. S. A. \& Hamid, A. \& Faradilla. (2017). Assessing the productivity of insurance companies in Indonesia : A non parametric approach. Journal of Applied Economic Sciences, 6(52), 15931605 .

Maksum, M. (2011). Pertumbuhan asuransi syariah di dunia dan Indonesia. Al-Iqtishad : Jurnal Ilmu Ekonomi Syariah (Journal of Islamic Economics), 3(1), 35-48.

Noreen, U. \& Ahmad, S. (2016). Cost Efficiency and Total Factor Productivity: An empirical analysis of Pakistan's insurance sector. The Lahore Journal of Economics. 21(1), 123-150.

[OJK] Otoritas Jasa Keuangan. (2018). Statistik Perasuransian 2018. Jakarta (ID), Otoritas Jasa Keuangan.

Rusydiana, A. S. (2018). Indeks Malmquist untuk pengukuran efisiensi dan produktivitas bank syariah di Indonesia. Jurnal Ekonomi dan Pembangunan. 26(1), 47-58.

Rusydiana, A. S., Laila, N. \& Sudana. (2019). Efisiensi dan produktivitas industri perbankan pada sistem moneter ganda di Indonesia. Jurnal Siasat Bisnis, 23(1), 50-66.

Saad, N. M. (2012). An analysis on the efficiency of takaful and insurance companies in Malaysia: A non parametric approach. Review of Integrative Business \& Economics Research, 1(1), 33-56.

Sabiti, M. B., Effendi, J. \& Novianti, T. (2017). Efisiensi asuransi syariah di Indonesia dengan pendekatan Data Envelopment Analysis. Al Muzara'ah, 5(1), 69-87.

Sulaeman, A. (2014). Pengaruh upah dan pengalaman kerja terhadap produktivitas karyawan kerajinan ukiran kabupaten Subang. Trikonomika, 13(1), 91-100. 
Sunarsih, S. \& Fitriyani, F. (2018). Analisis efisiensi asuransi syariah di Indonesia tahun 2014-2016 dengan metode Data Envelopment Analysis (DEA). Jurnal Ekonomi dan Keuangan Islam, 4(1), 9-21.

Suryoaji, O. \& Cahyono, E. F. (2019). Komparasi efisiensi \& produktivitas perusahaan asuransi jiwa konvensional dan syariah di Indonesia pada Tahun 2014-2017, dengan Pendekatan DEA \& Indeks Malmquist. Jurnal Ekonomi Syariah Teori dan Terapan, 6(9), 1877-1893.

Suzuki, Y. \& Sastrosuwito, S. (2011). Efficiency and productivity change of the Indonesian commercial banks. International Proceedings of Economics Development and Research, 7, 1014 .

Taib, C. A., Ashraf, M. S. \& Razimi, M. S. B. A. (2018). Productivity change in the efficiency of the insurance and takaful industry of Pakistan. Academy of Accounting and Financial Studies Journal, 22, 1-11.

Taib, C. A., Ashraf, M. S. \& Razimi, M. S. B. A. (2018). Technical, Pure Technical and Scale Efficiency: A non-parametric approach of Pakistan's insurance and takaful industry. Academy of Accounting and Financial Studies Journal, 22, 1-11.

Viverita, Wulandari, S. \& Cabanda, E. (2016). Determinants of cost efficiency and productivity growth of the Indonesian insurance industry. International Journal of Knowledge-Based Organizations (IJKBO), 6(2), 70-82.

Yaisawarng, S., Asavadachanukorn, P. \& Yaisawarng, S. (2014). Efficiency and productivity in the Thai non-life insurance industry. Journal of Productivity Analysis, 41(2), 291-306.

Yakob, R., Yusop, Z., Radam, A. \& Ismail, N. (2014). Two-stage DEA method in identifying the exogenous factors of insurers' risk and investment management efficiency. Sains Malaysiana, 43(9), 1439-1450. 